\title{
PENGARUH PEMBELAJARAN MODEL INKUIRI BERBANTUAN MEDIA VIDEO PADA HASIL BELAJAR DI TINGKAT SEKOLAH MENENGAH PERTAMA
}

\author{
Iswan Setiadi $^{1^{*}}$, Yudha Irhasyuarna ${ }^{2}$, Muhammad Kusasi ${ }^{3}$ \\ ${ }^{1}$ Guru Kimia MAN 1 Balangan, Kalimantan Selatan, Indonesia \\ e-mail: iswan.setiadi@gmail.com \\ ${ }^{2}$ Pendidikan IPA FKIP Universitas Lambung Mangkurat, Banjarmasin, Indonesia \\ e-mail: yudhairhasyuarna@ulm.ac.id \\ ${ }^{3}$ Pendidikan Kimia FKIP Universitas Lambung Mangkurat, Banjarmasin, Indonesia \\ e-mail: mkusasi_kimia@ulm.ac.id
}

$\begin{array}{lll}\text { Submit } & : 28-02-2021 & \text { Revision : 21-03-2021 } \\ \text { Accepted } & : 26-03-2021 & \text { Published : 01-04-2021 }\end{array}$

*Corresponding author: Iswan Setiadi

\begin{abstract}
Abstrak: Permasalahan yang masih sering terjadi dalam dunia pendidikan di Indonesia, khususnya di bidang IPA adalah masih kurang aktifnya peserta didik dalam proses pembelajaran. Model pembelajaran inkuiri dan penggunaan media video diharapkan mampu untuk menjawab permasalahan tersebut. Metode penelitian yang digunakan adalah Nonequivalent Control Group Design. Sampel penelitian menggunakan 69 orang peserta didik di kelas VIII SMP di Banjarmasin dan dibagi menjadi dua kelompok kelas, yaitu kelas kontrol dan eksperimen. Hasil penelitian ini menunjukkan bahwa terdapat perbedaan hasil belajar yang signifikan antara penggunaan model pembelajaran inkuiri berbantuan media video dengan pembelajaran konvensional. Tren keduanya menunjukkan hasil yang positif bahwa peningkatan hasil belajar terjadi di kedua permodelan pembelajaran.
\end{abstract}

Kata kunci: inkuiri, video pembelajaran, hasil belajar

\section{THE EFFECT OF LEARNING INQUIRY MODEL ASSISTED WITH VIDEO MEDIA ON LEARNING OUTCOMES AT THE JUNIOR HIGH SCHOOL LEVEL}

\begin{abstract}
The problem that still often occurs in the world of education in Indonesia, especially in the field of science is that students are still not active in the learning process. The inquiry learning model and the use of video media are expected to be able to answer these problems. The research method used is Nonequivalent Control Group Design. The research sample used 69 students at the 8th grade level of SMP in Banjarmasin who were divided into two class groups, namely the control class and the experimental class. The results of this study indicate that there are significant differences in learning outcomes between the use of video-assisted inquiry learning models and conventional learning. The trend of both shows positive results that the increase in learning outcomes occurs in both learning models.
\end{abstract}

Keywords: inquiry, learning videos, learning outcomes

\section{PENDAHULUAN}

Polemik dalam pembelajaran IPA di Indonesia cukup kompleks. Satu dari sekian banyak masalah yang terjadi adalah peran aktif peserta didik yang dirasa masih kurang. Ada beberapa faktor yang mendasari permasalahan ini, salah satunya adalah peranan guru yang dirasa masih dominan dalam mengajarkan materi (Rahayu dkk., 2018; Fahmi dkk., 2021). Hal ini cukup beralasan karena selama ini sudut pandang guru masih berputar pada ketuntasan materi sesuai kurikulum. Hal ini juga tergambar pada rendahnya capaian 
Setiadi, I., Irhasyuarna, Y., \& Kusasi, M. (2021). Pengaruh Pembelajaran Model Inkuiri berbantuan Media Video pada Hasil Belajar di Tingkat Sekolah Menengah Pertama.

kemampuan sains Indonesia secara nasional ketika diukur melalui penilaian oleh PISA 2018 (OECD, 2019). Capaian ini masih di bawah rata-rata yang diharapkan oleh PISA dan jauh tertinggal dibandingkan negara lain khususnya di Asia, seperti Jepang dan Cina.

Peserta didik kita terbiasa untuk diajarkan materi/bahan ajar secara drill dan "maraton" agar penguasaan materi cepat selesai (Setiadi \& Irhasyuarna, 2017; Fahmi \& Irhasyuarna, 2017). Peserta didik diajar dengan cara pemberian latihan dan tugas secara terus-menerus dan berulang kali hingga terbiasa mengerjakan tipe soal tersebut namun tidak bisa mengerjakan jika tipe soal dirubah sedikit saja, baik dari segi alur pengerjaannnya maupun proses dalam penyelesaiannya (Af'idayani dkk., 2018; Rahmawati dkk., 2020). Hal ini tentu berkebalikan dengan tujuan pembelajaran kita yang menginginkan peserta didik yang lebih aktif ambil bagian dalam proses pencarian masalah hingga tahap akhir penyelesaian masalah. Harapan kita mengenai pendidikan yang benar adalah membuat peserta didik paham apa yang telah mereka pelajari dibandingkan hanya sekedar merekamnya sebagai suatu memori belaka (Fahmi \& Irhasyuarna, 2017; Hunaidah dkk., 2020).

Pembelajaran yang bisa diterapkan untuk menyelesaikan permasalahan tersebut diantaranya dengan menggunakan model pembelajaran inkuiri. Inkuiri merupakan kegiatan dalam memperoleh informasi melalui pengamatan dan atau percobaan untuk memecahkan suatu masalah, secara sistematis kritis, analitis, dan logis (Putra, 2012; Damayanti, 2014). Inkuiri merupakan bagian inti dari kegiatan pembelajaran berbasis kontekstual (Al-Tabani, 2014). Pengetahuan dan keterampilan merupakan hasil dari menemukan sendiri. Pembelajaran dengan model inkuiri juga dapat ditopang dengan penggunaan media seperti video. Peserta didik akan menyaksikan penyampaian materi tentang masalah kontekstual melalui sebuah tayangan video, sehingga dapat menganalisis masalah dengan jelas dan bisa lebih memotivasi untuk memecahkan masalah tersebut. Sehingga pada akhirnya nanti tujuan pembelajaran diharapkan tercapai secara optimal.

\section{METODE PENELITIAN}

Metode penelitian ini menggunakan kuasi eksperimen dengan bentuk Nonequivalent Control Group Design. Peneliti ingin melihat dampak yang ditimbulkan dari model pembelajaran inkuiri berbantuan media video $\left(\mathrm{X}_{1}\right)$ dibandingkan pembalajaran konvensional $\left(\mathrm{X}_{2}\right)$. Perangkat yang digunakan merupakan hasil pengembangan terhadap perangkat pembelajaran yang sudah tersedia digunakan untuk mengajar namun disesuaikan dengan kebutuhan permodelan inkuiri terbimbing. Perangkat kemudian divalidasi oleh lima orang yang ahli dan praktisi di bidangnya masing-masing.

Populasi penelitian ini adalah peserta didik kelas VIII di salah satu SMP Negeri di Banjarmasin. Sampel penelitian kelas perlakuan berjumlah 35 peserta didik dan kelas kontrol berjumlah 34 peserta didik. Desain penelitian yang digunakan dalam penelitian ini adalah Nonequivalent Control Group Design. Populasinya diambil dari dua kelas yang berbeda dan dipilih secara acak. Secara rinci rancangan penelitian dapat dilihat pada Tabel 1.

\begin{tabular}{lccc} 
& Tabel 1. Rancangan penelitian Nonequivalent Control Group Design & \\
\hline Kelas & Pre-Test & Perlakuan & Post-Test \\
\hline Eksperimen & $\mathrm{O}_{1}$ & $\mathrm{X}_{1}$ & $\mathrm{O}_{2}$ \\
Kontrol & $\mathrm{O}_{1}$ & $\mathrm{X}_{2}$ & $\mathrm{O}_{2}$ \\
\hline
\end{tabular}

Keefektifan penelitian ini diukur melalui instrumen tes hasil belajar yang berpedoman pada indikator masing-masing rencana pembelajaran. Data diambil melalui hasil pre-test dan post-test hasil belajar peserta didik. Tes hasil belajar dan keterampilan proses sains mencakup 25 butir soal.

\section{HASIL DAN PEMBAHASAN}

Data hasil penelitian digambarkan pada Tabel 2, 3, dan 4 berikut.

Tabel 2. Uji normalitas

\begin{tabular}{ccccc}
\hline Kelas & $\mathbf{N}$ & $\mathbf{L}_{\mathbf{0}}$ & Ltabel & Keterangan \\
\hline Eksperimen & 35 & 0,02 & 0,1457 & $\mathrm{H}_{0}$ diterima (normal) \\
Kontrol & 34 & 0,05 & 0,1457 & $\mathrm{H}_{0}$ diterima (normal) \\
\hline
\end{tabular}

Berdasarkan hasil uji normalitas diperoleh data post-test kelas eksperimen $\mathrm{L}_{0}<\mathrm{L}_{\text {tabel }}$ dan data posttest kelas kontrol $\mathrm{L}_{0}<\mathrm{L}_{\text {tabel }}$ sehingga untuk kedua data $\mathrm{H}_{0}$ diterima. Hal tersebut berarti baik data post-test kelas eksperimen maupun kontrol berdistribusi normal. 
Tabel 3. Uji homogenitas

\begin{tabular}{cccccc}
\hline Kelas & $\mathbf{N}$ & $\mathbf{d b}=\mathbf{N}-\mathbf{1}$ & $\mathbf{F}_{\text {hitung }}$ & $\mathbf{F}_{\text {tabel }}$ & Keterangan \\
\hline Eksperimen & 35 & 34 & 0,88 & \multirow{2}{*}{1,78} & \multirow{2}{*}{$\mathrm{H}_{0}$ diterima (homogen) } \\
Kontrol & 34 & 33 & & & \\
\hline
\end{tabular}

Berdasarkan hasil uji homogenitas dapat disimpulkan bahwa $\mathrm{F}_{\text {hitung }}<\mathrm{F}_{\text {tabel }}$ sehingga $\mathrm{H}_{0}$ diterima. Hal tersebut berarti data post-test kelas eksperimen dan kontrol mempunyai varian yang homogen. Tabel 4. Uji T

\begin{tabular}{cccccc}
\hline Kelas & $\mathbf{N}$ & $\mathbf{d b}=\mathbf{N}-\mathbf{1}$ & $\mathbf{t}_{\text {hitung }}$ & $\mathbf{t}_{\text {tabel }}$ & Keterangan \\
\hline Eksperimen & 35 & 34 & & & \\
Kontrol & 34 & 33 & 2,10 & 1,99 & Berbeda Signifikan \\
Jumlah & 69 & 67 & & & \\
\hline
\end{tabular}

Berdasarkan hasil $\mathrm{N}$-gain, harga t-hitung yang diperoleh kemudian dibandingkan dengan harga ttabel untuk membuktikan hipotesis yang diajukan. Berkaca pada hasil penghitungan dapat disimpulkan bahwa $t_{\text {hitung }}>t_{\text {tabel }}$ sehingga $\mathrm{H}_{0}$ ditolak. Hal tersebut berarti terdapat perbedaan yang signifikan antara $N$ gain kelas eksperimen dan kontrol atau dengan kata lain kelas eksperimen dan kontrol setelah pembelajaran mempunyai peningkatan pemahaman yang berbeda.

Secara garis besar antara penggunaan model inkuiri berbantuan media video dan pembelajaran konvensional mengalami kecenderungan peningkatan hasil belajar dari pre-test menuju post-test. Peningkatan ini terjadi bisa dipahami sebagai sebuah proses belajar pada diri peserta didik yang menyerap pengetahuan baru. Pada tahap awal peserta didik mungkin akan kesulitan dalam menerapkan model inkuiri terbimbing karena faktor belum terbiasa dengan pola belajar tersebut. Namun seiring berjalan waktu harapannya peserta didik akan mulai terbiasa dengan model inkuiri dan juga dibantu dengan media video yang memotivasi lebih cepat untuk mendalami permalahan dan pemecahan masalah. Hal ini didukung oleh penelitian Fairuzabadi dkk. (2017) yang menyatakan pembelajaran menggunakan model pembelajaran inkuiri terbimbing dengan video berbasis kontekstual mampu meningkatkan partisipasi peserta didik dalam aktivitas belajarnya. Sabahiyah (2013) menjelaskan model pembelajaran inkuiri terbimbing berpengaruh terhadap pemahaman konsep IPA peserta didik.

Berdasarkan hasil uji t terhadap kemampuan akhir peserta didik didapatkan bahwa nilai belajar peserta didik berbeda secara signifikan antara kelas yang menerapkan model inkuiri berbantuan media video dan konvensional. Terdapat perbedaan signifikan yang terjadi karena perlakuan yang diberikan berpengaruh pada pemahaman peserta didik baik berupa penggunaan model yang tepat maupun media yang baik dan benar. Media pembelajaran dapat digunakan sebagai alat untuk mempermudah dan juga menambah ketertarikan peserta didik dalam menyimak isi pembahasan materi. Selain itu dapat menampilkan sesuatu yang bersifat abstrak, sehingga memiliki nilai praktis yang tinggi. Pendapat ini didukung oleh Sanjaya (2011) yang menyebutkan media pembelajaran memiliki nilai praktis antara lain mengatasi keterbatasan pengalaman yang dimiliki peserta didik, mengatasi batas ruang kelas, benar, nyata, dan tepat, dapat memungkinkan terjadinya interaksi langsung antara peserta didik dan lingkungan, menghasilkan keseragaman pengalaman, dapat menanamkan konsep dasar yang membangkitkan motivasi, keinginan dan minat, serta media dapat mengontrol kecepatan belajar peserta didik. Senada dengan penelitian Yuliastutik (2014) bahwa model pembelajaran inkuiri terbimbing yang menggunakan media pembelajaran berbasis audiovisual berdampak terhadap hasil belajar peserta didik dalam pembelajaran IPA. Video sebagai media pendukung pembelajaran memfasilitasi peserta didik agar minat serta pemahaman terhadap materi yang disajikan bisa lebih jauh meningkat.

\section{SIMPULAN}

Penelitian ini memperlihatkan peningkatan terjadi pada peserta didik setelah mendapat intervensi inkuiri dalam belajarnya. Secara kuantitatif ditemukan fakta model inkuiri meningkatkan hasil belajar peserta didik. Tren positif terjadi menunjukkan adanya proses belajar dan dibantu dengan media video pembelajaran akan mempermudah pelaksanaan pembelajaran menggunakan model inkuiri terbimbing di kelas. 
Setiadi, I., Irhasyuarna, Y., \& Kusasi, M. (2021). Pengaruh Pembelajaran Model Inkuiri berbantuan Media Video pada Hasil Belajar di Tingkat Sekolah Menengah Pertama.

\section{DAFTAR PUSTAKA}

Af'idayani, N., Setiadi, I., \& Fahmi. (2018). The Effect of Inquiry Model on Science Process Skills and Learning Outcomes. European Journal of Education Studies, 4 (12), 177-182. Doi: 10.5281/zenodo.1344846.

Al-Tabani \& Trianto. (2014). Mendesain Model Pembelajaran Inovatif, Progresif, dan Kontekstual. Surabaya: Prenadamedia Group.

Damayanti, I \& Mintohari. (2014). Penerapan Model Pembelajaran Inkuiri untuk Meningkatkan Hasil belajar Mata Pelajaran IPA Sekolah Dasar. JPGSD, 2 (3).

Fahmi., Abdullah., \& Irhasyuarna, Y. (2021). Empowering Peat Lands as a Resource of Learning Natural Science to Strengthening Environment Care. The 2nd International Conference on Social Sciences Education (ICSSE 2020), 426-429. Doi: 10.2991/assehr.k.210222.072.

Fahmi \& Irhasyuarna, Y. (2017). Misconceptions of Reaction Rates on High School Level in Banjarmasin. IOSR Journal of Research \& Method in Education (IOSR-JRME), 7 (1), 54-61. Doi: 10.9790/73880701045461.

Fahmi \& Irhasyuarna, Y. (2017). The Misconceptions of Senior High School Student in Banjarmasin on Chemical Bonding. Journal of Education and Practice, 8 (17), 32-39.

Fairuzabadi, A., Prihandono, T., \& Putra, P.D.A. (2017). Penerapan Model Pembelajaran Inkuiri Terbimbing dengan Video Berbasis Kontekstual dalam Pembelajaran IPA pada Materi Suhu dan Pengukurannya di SMP. Jurnal Pembelajaran Fisika, 6(1), 100-106.

Hunaidah M., Erniwati., \& Sukariasih, L. (2020). Meningkatkan Hasil Belajar dan Keterampilan Inkuiri Peserta Didik pada Materi Pokok Tekanan Zat melalui Penerapan Model Argument Driven Inquiry (ADI). Journal of Banua Science Education (JBSE), 1 (1), 15-20. E- ISSN: 2745-7222. Doi: 10.20527/jbse.v1i1.4. http://jbse.ulm.ac.id/index.php/JBSE/issue/view/2

OECD. (2019). PISA 2018 Results (Volume I): What Students Know and Can Do. Paris: OECD Publishing.

Putra, S.R. (2012). Desain Belajar Mengajar Kreatif Berbasis Sains. Jogyakarta: Diva Press.

Rahayu, A.B., Hadi, S., Istyadji, M., Zaini, M., Sholahuddin, A., \& Fahmi. (2018). Development of Guided Inquiry Based Learning Devices to Improve Student Learning Outcomes in Science Materials in Middle School. European Journal of Alternative Education Studies, 3 (2), 107-117. Doi: 10.5281/zenodo.2261027.

Rahmawati, I., Mastuang., Suyidno., \& Sunarti, T. (2020). Kelayakan Bahan Ajar Elastisitas dan Hukum Hooke Berbasis Inkuiri Terbimbing untuk Melatihkan Keterampilan Proses Sains Peserta Didik. Journal of Banua Science Education (JBSE), 1 (1), 21-28. E- ISSN: 2745-7222. Doi: 10.20527/jbse.v1i1.1. http://jbse.ulm.ac.id/index.php/JBSE/issue/view/2

Sabahiyah., Marhaeni, \& Suastra. (2013). Pengaruh Model Pembelajaran Inkuiri Terbimbing terhadap Keterampilan Proses Sains dan Penguasaan Konsep IPA Siswa Kelas V Gugus 3 Wanasaba Lombok Timur. E-Journal Program Pascasarjana Universitas Pendidikan Ganesha, 3 (1).

Sanjaya, W. (2011). Strategi Pembelajaran Berorientasi Standar Proses Pendidikan. Jakarta: Kencana Prenada Media, Cetakan ke-8.

Setiadi, I \& Irhasyuarna, Y. (2017). Improvement of Model Student Learning Through the Content of Solutions Guided Discovery Buffer. IOSR Journal of Research \& Method in Education (IOSR-JRME), 7 (1), 1-9.

Yuliastutik, S., Sudarti., \& Supriadi, B. (2014). Dampak Model Inkuiri Terbimbing disertai Media Pembelajaran Berbasis Audiovisual terhadap Sikap Ilmiah dan Hasil Belajar IPA Siswa Kelas VIII di SMPN 1 Maesan. Jurnal Pembelajaran Fisika, 3 (3), 216-222. 